\title{
Prediction of Groundwater Dynamics for Sustainable Water Resource Management in Bogra District, Northwest Bangladesh
}

\author{
Mohammad Hasanuzzaman ${ }^{1,2}$, Xianfang Song ${ }^{1,2, *}$, Dongmei Han ${ }^{1,2}$, Yinghua Zhang ${ }^{1}$ and \\ Shakir Hussain ${ }^{1}$ \\ 1 Key Laboratory of Water Cycle and Related Land Surface Processes, Institute of Geographic Sciences and \\ Natural Resources Research, Chinese Academy of Sciences, Beijing 100101, China; \\ hasanbina@gmail.com (M.H.); handm@igsnrr.ac.cn (D.H.); zhangyinghua@igsnrr.ac.cn (Y.Z.); \\ shakir.hussain.geography@hotmail.com (S.H.) \\ 2 University of Chinese Academy of Sciences, Beijing 100049, China \\ * Correspondence: songxf@igsnrr.ac.cn; Tel.: +86-10-6488-9849
}

Academic Editor: Xiangzheng Deng

Received: 20 November 2016; Accepted: 24 March 2017; Published: 28 March 2017

\begin{abstract}
The green revolution in the northwest region of Bangladesh over the past three decades has based on groundwater irrigation. For sustainable agricultural accretion, groundwater dynamics play a vital role in this region. In this study, the groundwater level dynamics have been analyzed with a model named "MAKESENS" and with geographical information systems (GIS). The study indicates that, in most of the wells, the water table (WT) depth and the rainfall intensity are declining slowly. The prediction of WT depth during the period of 2020, 2040, and 2060 indicate that, in some cases, the WT depth will approximately double by the year 2060, considering the present declining trend. This result suggests that, for the sustainable management of groundwater, necessary measures should be adopted to avoid or reduce the severe ecological, social, and economic impacts of groundwater mining. Moreover, crop diversification, conservation techniques, increasing irrigation efficiency, rainwater harvesting, etc. can be adopted to avoid groundwater declination and consequently to enhance the sustainable use of groundwater resources in the area.
\end{abstract}

Keywords: groundwater dynamics; MAKESENS model; sustainable water use; water table depth; Bangladesh

\section{Introduction}

Groundwater is an important resource serving as a reliable source of water for irrigation, and domestic and industrial purposes in many countries. The growth of population, food insecurity, rising economies, and poor water management are putting unusual pressure on the world's freshwater resources [1]. Due to the lack of surface water resources, groundwater is the most essential prerequisite for increasing crop production, as well as for the sustainable agricultural development. In many areas of the world, irrigation is critical to food security and groundwater use has increased to become a major source for irrigation water, especially in China and South Asia [2,3].

Bangladesh, though, is blessed with abundant groundwater resources, but not unlimited. A large quantity of groundwater is being pumped each year, mainly for irrigation, and domestic and industrial uses, through different water lifting devices. Availability of groundwater for irrigation has contributed to a manifold increase in crop productivity in Bangladesh. Over the past few decades most of the rivers and canals of the region have dried up during the dry season and the people switched their water supply from surface to groundwater [4-6]. The main supply of groundwater for irrigation is 
from shallow tube-wells (STW), the numbers of which have grown from around 100,000 in the early 1980s to more than 1.5 million today [7]. Over-extraction of groundwater for irrigation, industrial, and domestic purposes during the dry season, has quickened the groundwater level depletion in such a way that, in some points, it is not fully recharging during the rainy season.

The northwest part of Bangladesh, the Barind Tract, located mostly in the greater districts of Rajshahi, Bogra, and Dinajpur, have a gross area of $7727 \mathrm{~km}^{2}$ [8]. Long-term (1981-2013) average annual rainfall of Bogra district is about $1754 \mathrm{~mm}$, while the national average is about $2300 \mathrm{~mm}$. The national water policy of the Bangladesh government inspired groundwater development for irrigation both in the public and the private sectors. Groundwater irrigation has probably been developed in Bangladesh agriculture since the 1980s. The groundwater-based irrigation project in the area, named as the Barind Multipurpose Development Authority (BMDA), has accelerated the use of groundwater, installing deep tube wells (DTWs) in 1986. In addition, STWs are also installed by the private sectors for the exploitation of groundwater for irrigation. Within the crop sector, food production is dominated by irrigated Boro rice. The use of groundwater in this region is much higher compared to other parts of the country due to the lack of surface water resources and major irrigated agricultural sites of the country. In some parts of the country, farmers have been forced to replace their suction mode pumps with submersible pumps because of the continuous decline in groundwater levels. The groundwater level is declining due to overuse of groundwater [9-11]. Overexploitation of groundwater has been reported for some parts of Pakistan [12], India [13], Sri Lanka [14], and China [3]. WT depth is also declining owing to climatic factors, especially rainfall [15]. This decline happens due to insufficient recharge, which is caused by lower rainfall than that of the other regions of the country and its erratic distribution throughout the year.

In order to improve and utilize groundwater resources reasonably, and formulate water managing and protecting policies for government, it is important to conduct research on groundwater resource evaluation and groundwater environmental protection. Devlin and Sophocleous [16] mentioned that sustainability of groundwater is a function both of recharge and pumping. Groundwater management practices should be used in a sustainable manner to maintain them for future generations [17]. Alley and Leake [18] defined sustainable groundwater yield as the use of groundwater in a manner that can be maintained for a long time without causing unfavorable environmental, economic, or social consequences. A number of researchers have studied the WT depth dynamics and its long-term trend based on the MAKESENS model for the northeastern Mymensingh district [9], the northwestern Rajshahi district [11], and the Chapai-Nawabganj, Naogaon, and Rajshahi districts [19] of Bangladesh. All of them, except for [11], have not addressed the confidence level of their trend test and residual distribution for the Sen's slope, nor have any of them even shown a long-term future rainfall projection. For the sustainable use of the resource, the groundwater level dynamics of the region, the present trend and future scenario would be useful in future planning of groundwater use in the region.

The objectives of the study are: (i) to analyze the historical dynamics of groundwater level; (ii) to predict the groundwater level for the future using computer software "MAKESENS" and (iii) to realize sustainable groundwater use in the region.

\section{Materials and Methods}

\subsection{Site Description}

The study area is characterized by two distinct land forms: the undulating Barind tract and the floodplains which are mainly occupied with Pleistocene deposits [20]. Geographically, this region is lying between $88^{\circ} 20^{\prime}$ to $89^{\circ} 30^{\prime} \mathrm{E}$ and $24^{\circ} 20^{\prime}$ to $25^{\circ} 35^{\prime} \mathrm{N}$. The Barind area is floored by Madhupur clay. The present study is based on part of a configuration of three greater districts of the Barind tract (Bogra district, which has an area of $2919.9 \mathrm{~km}^{2}$, situated between $89^{\circ} 22^{\prime} \mathrm{E}$ and $24^{\circ} 51^{\prime} \mathrm{N}$, comprised of 11 sub-districts called "Upazila"). A location map of the study area is shown in Figure 1. 


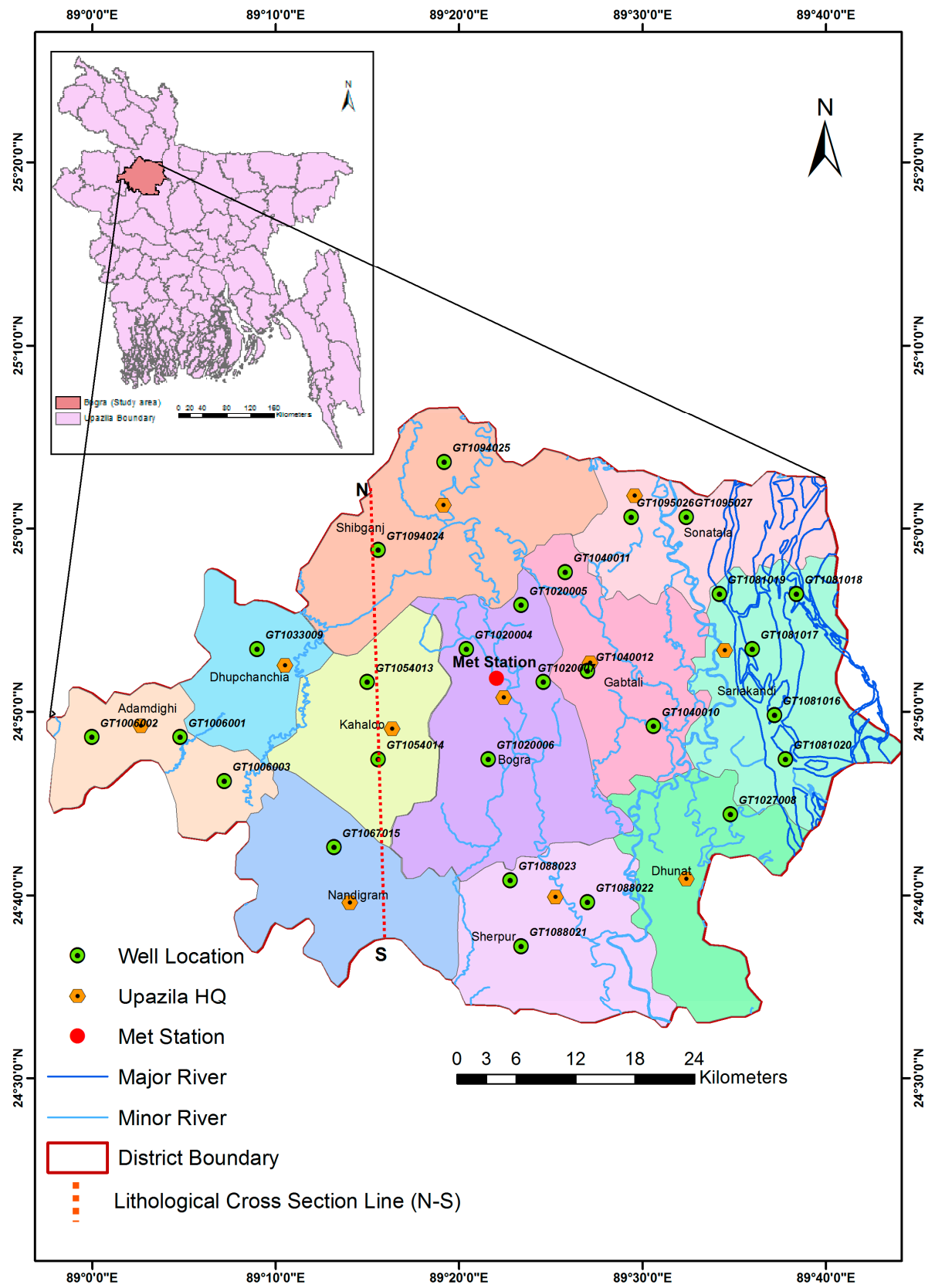

Figure 1. Location of the study area and groundwater monitoring wells. The orange dotted line represents the lithological cross section (Figure 2).

The long-term (33 years) WT depth data, from 1981 to 2013, were collected from the Bangladesh Water Development Board (BWDB). In the area, 27 observation wells have been in use for groundwater level monitoring. The number of observation wells with elevation and coordinates under each Upazila is given in Table 1. For more than 33 years monthly meteorological data were collected from the Bangladesh Meteorological Department (BMD) situated in the study area. The long-term data of the irrigated area are mainly covered by STW with a $5-10 \mathrm{~cm}$ diameter, extracting water with a centrifugal pump, and DTW, with a 15-20 cm diameter, operating with a submersible turbine pump. Information about the irrigated area, as well as the major crop production area, has been collected from the Bangladesh Bureau of Statistics (BBS). Data were analyzed using MAKESENSE model [21] software, Origin lab 9.0, and MS Excel. Additionally, Arc GIS 10.1 software was used for image processing. 
Table 1. Well numbers under different Upazilla of Bogra district used for the study.

\begin{tabular}{|c|c|c|c|c|c|}
\hline No. & Upazila (Sub District) & Well No. & Elevation (m) & Longitude $\left({ }^{\circ}\right)$ & Latitude $\left({ }^{\circ}\right)$ \\
\hline \multirow{3}{*}{1} & \multirow{3}{*}{ Adamdighi } & GT1006001 & 17.22 & 89.08 & 24.81 \\
\hline & & GT1006002 & 15.65 & 89.00 & 24.81 \\
\hline & & GT1006003 & 15.24 & 89.12 & 24.77 \\
\hline \multirow{4}{*}{2} & \multirow{4}{*}{ Bogra Sadar } & GT1020004 & 15.80 & 89.34 & 24.89 \\
\hline & & GT1020005 & 18.96 & 89.39 & 24.93 \\
\hline & & GT1020006 & 16.98 & 89.36 & 24.79 \\
\hline & & GT1020007 & 17.40 & 89.41 & 24.86 \\
\hline 3 & Dhunot & GT1027008 & 15.21 & 89.58 & 24.74 \\
\hline 4 & Dupchanchia & GT1033009 & 19.06 & 89.15 & 24.89 \\
\hline \multirow{3}{*}{5} & \multirow{3}{*}{ Gabtali } & GT1040010 & 15.87 & 89.51 & 24.82 \\
\hline & & GT1040011 & 17.60 & 89.43 & 24.96 \\
\hline & & GT1040012 & 16.67 & 89.45 & 24.87 \\
\hline \multirow{2}{*}{6} & \multirow{2}{*}{ Kahalu } & GT1054013 & 16.67 & 89.25 & 24.86 \\
\hline & & GT1054014 & 17.40 & 89.26 & 24.79 \\
\hline 7 & Nandigram & GT1067015 & 14.26 & 89.22 & 24.71 \\
\hline \multirow{5}{*}{8} & \multirow{5}{*}{ Sariakandi } & GT1081016 & 16.55 & 89.62 & 24.83 \\
\hline & & GT1081017 & 17.04 & 89.60 & 24.89 \\
\hline & & GT1081018 & 15.75 & 89.64 & 24.94 \\
\hline & & GT1081019 & 17.60 & 89.57 & 24.94 \\
\hline & & GT1081020 & 17.23 & 89.63 & 24.79 \\
\hline \multirow{3}{*}{9} & \multirow{3}{*}{ Sherpur } & GT1088021 & 17.22 & 89.39 & 24.62 \\
\hline & & GT1088022 & 15.91 & 89.45 & 24.66 \\
\hline & & GT1088023 & 15.77 & 89.38 & 24.68 \\
\hline \multirow{2}{*}{10} & \multirow{2}{*}{ Shibganj } & GT1094024 & 19.91 & 89.26 & 24.98 \\
\hline & & GT1094025 & 20.58 & 89.32 & 25.06 \\
\hline \multirow[b]{2}{*}{11} & \multirow[b]{2}{*}{ Sonatola } & GT1095026 & 17.90 & 89.49 & 25.01 \\
\hline & & GT1095027 & 18.26 & 89.54 & 25.01 \\
\hline
\end{tabular}

\subsection{Physiography and Hydrogeological Conditions}

The topography of the region is characterized by two distinguished landforms: (a) the Barind area, which has irregular topography, and (b) the floodplains. The elevated Barind area is characterized by less infiltration due to clayey and semi- to impermeable Barind clay with excessive surface runoff. Morpho-stratigraphically, the Barind area is subdivided into three geological units: (1) Barind clay residuum overlies and developed on Pleistocene alluvium; (2) Holocene Ganges flood-plain alluvium; and (3) active channel deposits of the Ganges and major Tributaries (modern alluvium). The subsurface lithology covers alluvial sand, alluvial silt, Barind clay residuum, and Marsh clay and peat. Hydrogeological, the area is comprised of semi-impervious recent-Pleistocene clayey silt aquitard (thickness 3.0-47.5 m) which overlays a single- to multiple-layered (2-4) aquifer system of Plio-Pleistocene age (thickness 5.0-42.5 m) [22]. Moreover, for the study region, a recent study [23] identified that the subsurface lithology is composed of mostly clay to silty clay $(\sim 10 \mathrm{~m})$ at the upper-most layer and fine to coarse sands, downward (Figure 2).

\subsection{Climatic Behavior of the Region}

The annual rainfall from 1981 to 2013 in the study area varies from 1106 to $2601 \mathrm{~mm}$. It also delineates regular positive and negative anomalies over time, as shown in Figure 3. The ratio of rainfall from May to September with the total annual rainfall is approximately $84 \%$. The yearly rainfall fluctuates considerably, with mean, standard deviation, and a coefficient of variation of $1754 \mathrm{~mm}$, $399 \mathrm{~mm}$, and $23 \%$, respectively. Long-term monthly average maximum temperature varies from 23 to $35{ }^{\circ} \mathrm{C}$ and average minimum temperature varies from 10 to $26^{\circ} \mathrm{C}$. The long-term average relative humidity varies from $34 \%$ to $74 \%$. 


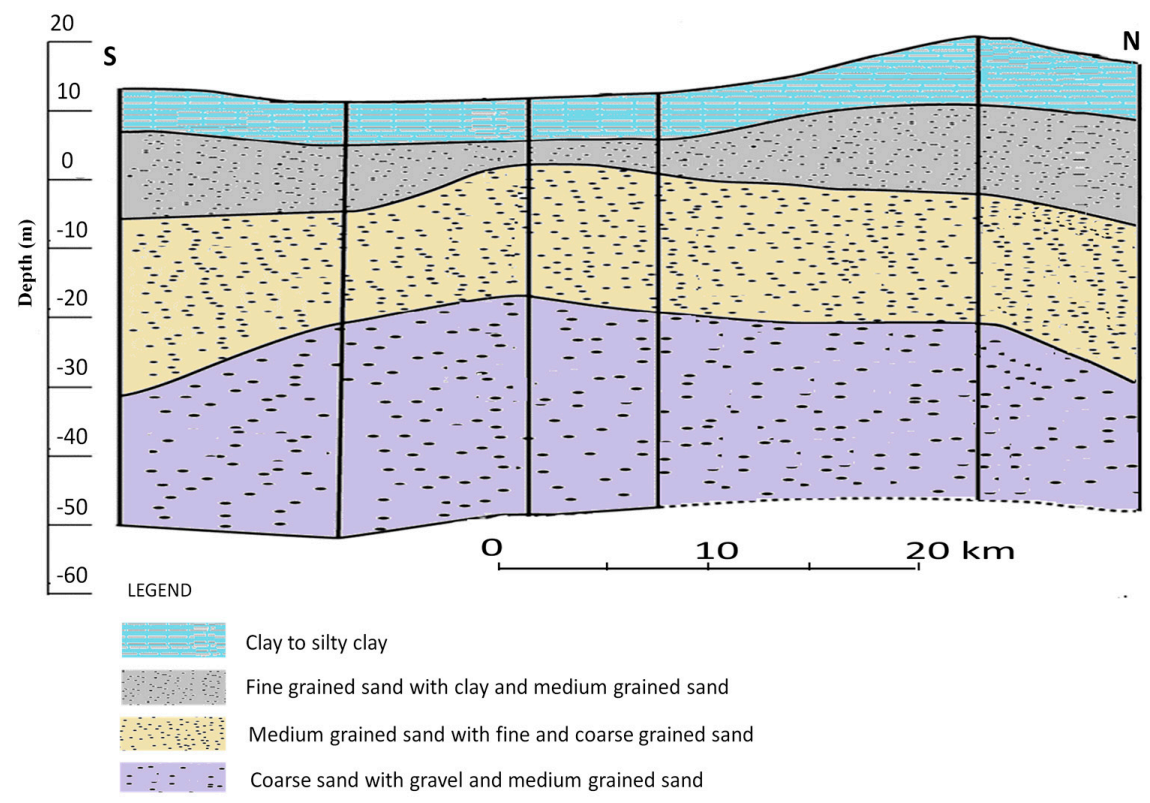

Figure 2. Lithological cross section of the study area.
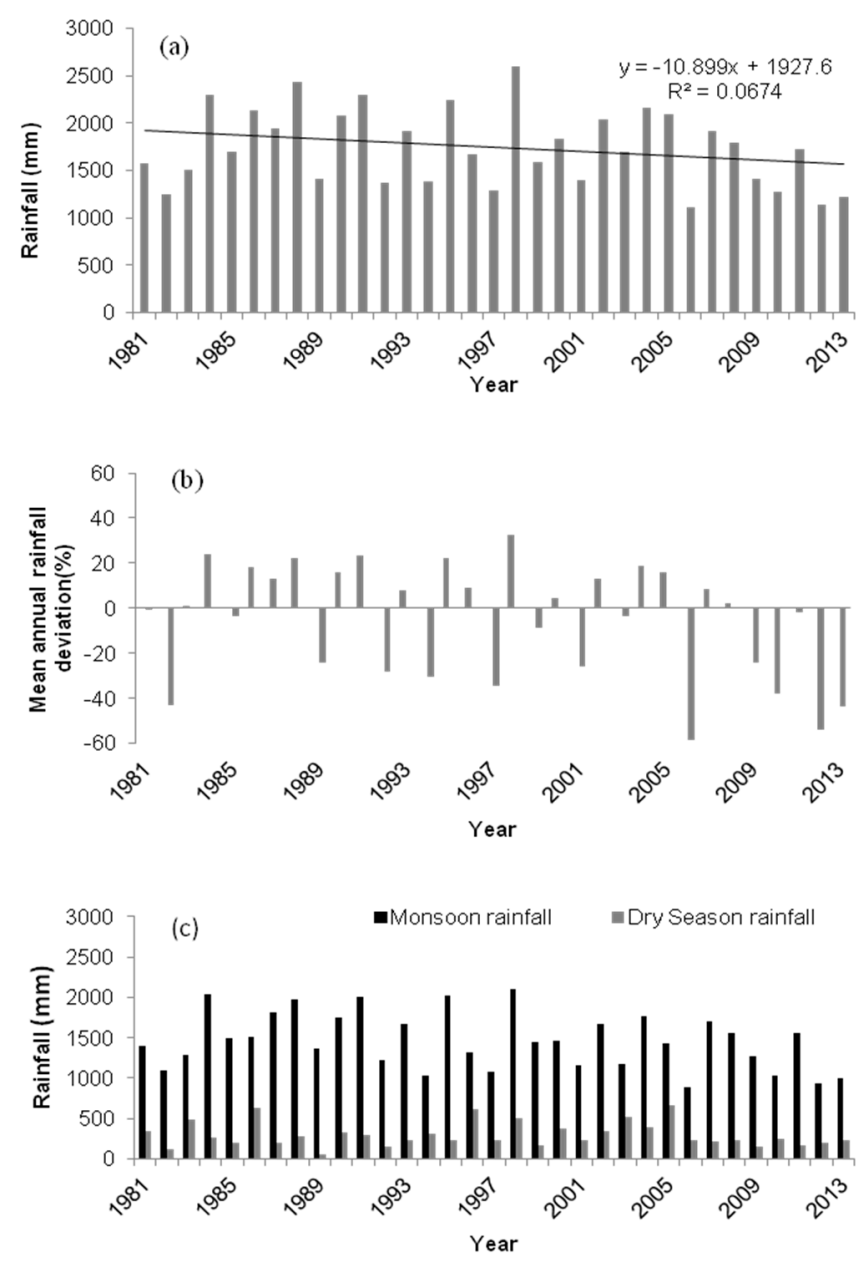

Figure 3. (a) Long-term rainfall pattern (b) Mean annual rainfall deviation and (c) Long term seasonal rainfall variation in the study area. 


\subsection{WT Dynamics}

The long-term patterns of WT depth are presented graphically to explain the dynamic behavior of the groundwater level. Several methods have been applied for analyzing the trend of meteorological and hydrological data, including parametric (linear regression) as well as non-parametric approaches. Widely used has been time-series analysis, such as the Mann-Kendall trend test and Sen's slope estimator in hydrological analysis [19,24-26]. To detect and estimate the simulated trends of the maximum WT depth, the "MAKESENS" software was used [9], which is based on the non-parametric Mann-Kendall test for trends and the non-parametric Sen's method for the magnitude of the trend [21]. The Mann-Kendall trend test is a rank-based non-parametric test originally developed for non-correlated data. Not only can it detect any possible trend in temperature or hydrological series, but it can also test whether such trends are statistically significant or not. This test checks the null hypothesis of no trend versus the alternative hypothesis of an increasing or decreasing trend. Moreover, this test does not require that the data fit a normal distribution. More generally, nonparametric tests require less restrictive assumptions about the data. Another important reason for these tests is that they allow for the analysis of categorical as well as ranked data. It is important to note that, even with metric data, if assumptions are badly violated, nonparametric tests are likely to be employed. The advantage of non-parametric method is that it is applicable for monotonic trend, and there is no problem with the missing data. The model also exploits both the so-called $\mathrm{S}$ statistics and $\mathrm{Z}$ statistics (the normal approximation) given by [27]. For time series with fewer than 10 data points, the $S$ test is used; for time series with 10 or more data points, the $Z$ test is used.

When the data values $x_{i}$ of a time series can be assumed to obey the following model (Equation (1)), the Mann-Kendall test is valid:

$$
x_{i}=f\left(t_{i}\right)+\varepsilon_{i}
$$

where $f(t)$ is a continuous monotonic increasing or decreasing function of time and the residuals $\varepsilon_{i}$ can be assumed to be from the same distribution with a zero mean.

In case of data values $<10$, the number of annual values in the studied data series is denoted by $n$ and the Mann-Kendall test statistic $(S)$ is calculated as

$$
S=\sum_{k-1}^{n-1} \sum_{j-1}^{n} \operatorname{sgn}\left(x_{j}-x_{k}\right)
$$

where $x_{\mathrm{j}}$ and $x_{k}$ are the annual values in years $j$ and $k$, respectively, $(j>k)$, and

$$
\operatorname{sgn}\left(x_{j}-x_{k}\right)=\left[\begin{array}{c}
1 \text { if }\left(x_{j}-x_{k}\right)>0 \\
0 \text { if }\left(x_{j}-x_{k}\right)=0 \\
-1 \text { if }\left(x_{j}-x_{k}\right)<0
\end{array}\right]
$$

When the value of $n$ is 9 or less, the absolute value of $S$ is compared with the theoretical distribution of $S$ derived by Mann and Kendall [27]. In MAKESENS the tested significance levels $\alpha$ are $0.1,0.05$, 0.01 , and 0.001 .

Further details in relation to the MAKESENS software can be found in [21]. The WT depths were projected [9] as

$$
\text { WT depth }(\mathrm{m})=\mathrm{B}+\mathrm{Q} \times(\text { Simulation year }- \text { Base year })
$$

where $B$ is the intercept, and $Q$ is the slope of the trend line, the projections were made for the years 2020, 2040, and 2060. The year 1981 was considered as the base year.

\section{Results of the Historical Data Analysis}

\subsection{Impact of Irrigation Equipment on Crop Area}

In the Barind area, different irrigation equipment has been introduced significantly in order to fulfill the increasing demand for food production as well as for the deficit of rainfall in during the dry 
season. This is because of liberalization of government policy (1979) on procurement, installation, and management of irrigation equipment [28]. Therefore, after the 1980s, farmers installed a large number of STWs and DTWs indiscriminately for obtaining higher production, owing to achieving the goal of food security. Especially, farmers grow Boro rice during the dry season, which requires $0.4-1.5 \mathrm{~m}$ of irrigation which is almost completely groundwater-fed [29]. Approximately 4.2 million ha of land is irrigated by groundwater, whereas only 1.03 million ha is irrigated by surface water [30]. Continually increasing patterns of irrigated area under major irrigation equipment (STW and DTW) during 1980 to 2010 is shown in Figure 4. The irrigated areas by major equipment (STW and DTW) are almost 12,000 and 10,000 ha in 1980 and increased to around 275,000 and 102,000 ha, respectively, in 2010.

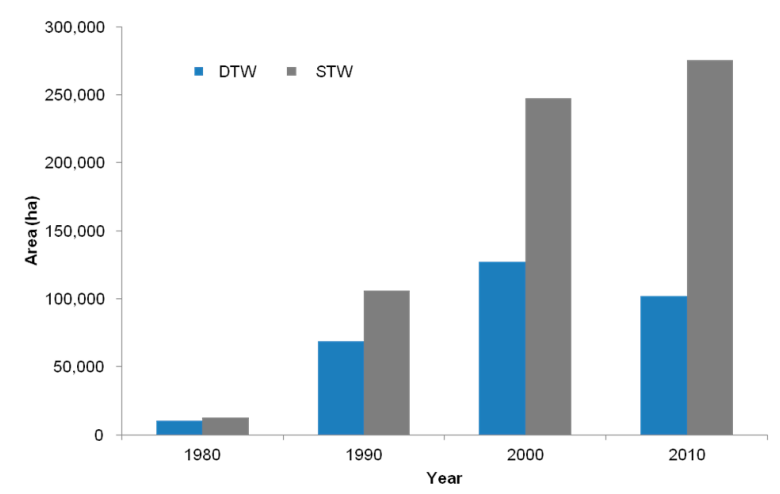

Figure 4. Changes in irrigated area by STW and DTW over time in the study area.

\subsection{Impact on the Major Crop Production}

The increasing rate of Boro rice area was abruptly high between 1981 and 2000 resulting mainly from expansion of groundwater-fed irrigation facilities (Figure 5) because Boro rice is grown in the dry season while groundwater is the dominant source of irrigation. On the other hand, Boro rice production was nearly static during the last decade (2000-2010), while other products (e.g., Potato) increased significantly (Figure 5). The production area of Boro rice in Bangladesh has increased more than three-fold in past few decades [31]. The practice of irrigating fields, thus, opens the water access facility automatically for Boro rice production, which restricts the farmers' options for other crops. Nevertheless, with respect to the scope of the marginal increase of other crops, production stems from a gradual decrease in Boro rice areas caused by factors like the cost of irrigation, water scarcity, and/or preference for high-value crops.

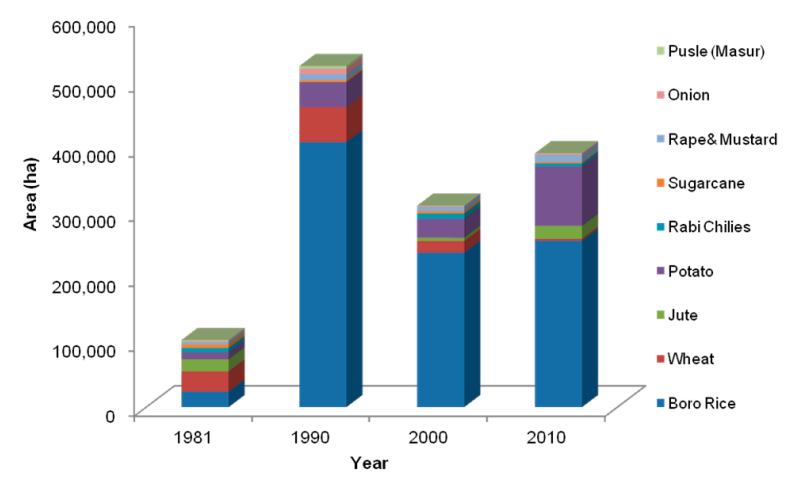

Figure 5. Cultivated crop production over time in the study area.

\subsection{WT Dynamics}

The average long-term WT depth fluctuation is very significant for the study area and this depicts that the trend over the years 1981-2013 are declining (Figure 6a). Moreover, the long-term rainfall 
in this area also shows similar significant changes as that of WT depth (Figure 6a). This means that when the rainfall is high, then the WT depth is low. However, the WT depth is partially dependent on the temporal rainfall pattern (Figure $6 b$ ). The correlation factor (i.e., $r$ which is the square root of $\mathrm{R}^{2}$ ) for these two parameters is 0.58 (Figure $6 \mathrm{~b}$ ). In addition, herein, the seasonal variation pattern of these two events is also carried out. For instance, the maximum and minimum WT depth of well GT1020005 for different specific years, and the rainfall for the respective years are presented graphically in Figure 7. The monthly pattern of the hydrograph shows that the WT depth increases during March-April and decreases or regains its position during May-September. The graph indicates a lower amount of rainfall during the dry season (November-April) and higher amounts during the rainy season (May-September). Accordingly, WT depths are changing with the same pattern. The difference between the maximum and minimum WT depth was becoming narrower, implying that there was inadequate recharge in the aquifer. From the graph it is clear that rainfall plays an important role for groundwater replenishment, with the exception of the record in June 1990.

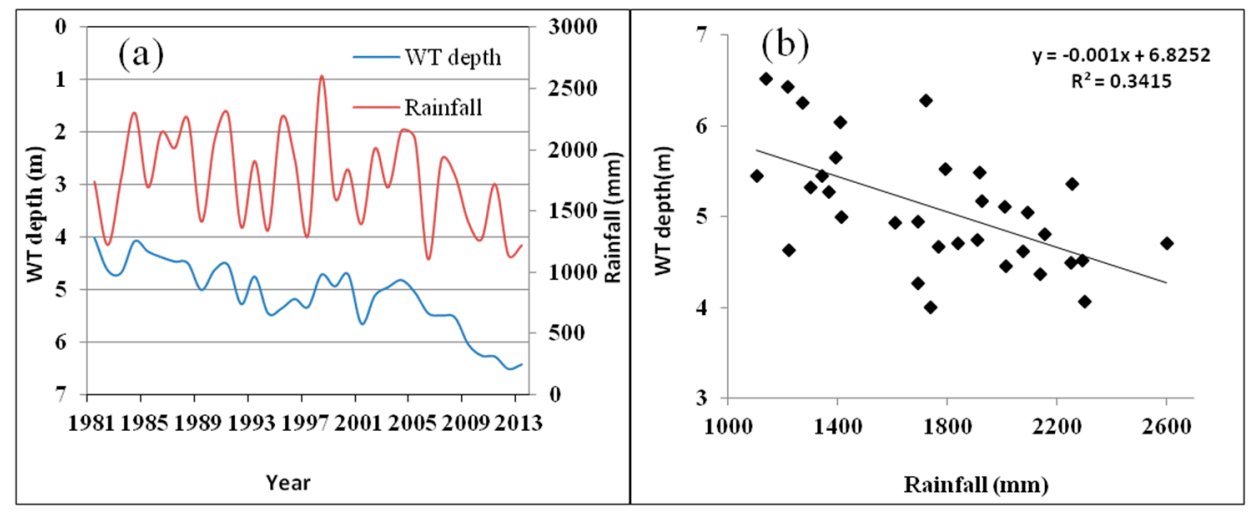

Figure 6. Long-term average WT depth and rainfall changes pattern (a); and correlation (b).

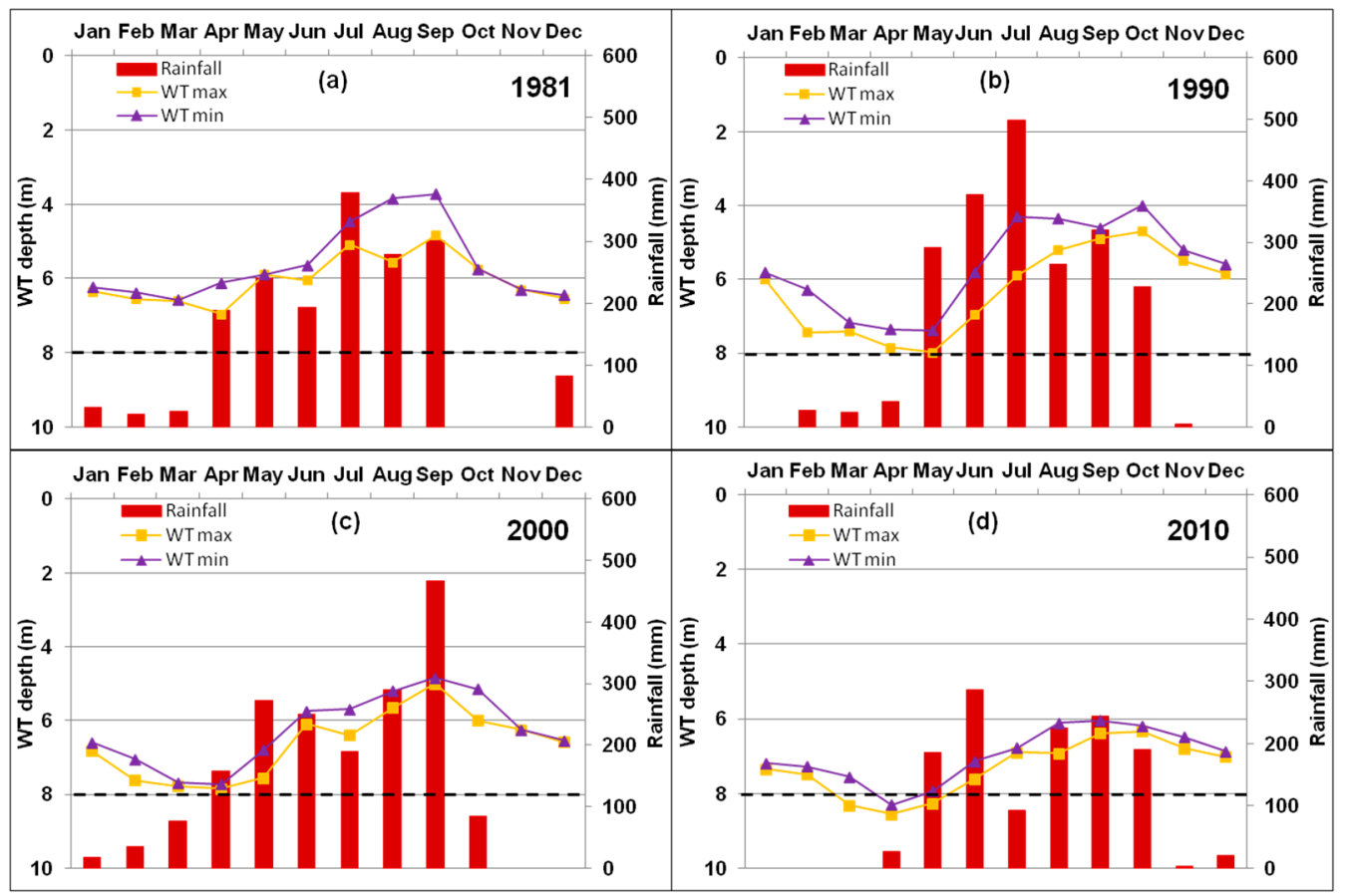

Figure 7. Monthly maximum and minimum WT depth hydrograph and rainfall distribution pattern in the respective year for (a) 1981, (b) 1990, (c) 2000 and (d) 2010. (Well No. GT1020005). 


\subsection{Long-Term Pattern of Yearly Data}

The long-term (1981-2013) hydrograph of yearly maximum WT depth under different Upazilas are shown in Figure 8. In this figure, it is observed that the WT depth is beyond the suction limit for 12 wells out of 27 wells in the area. In the rest of the wells, it is also practically impossible to withdraw water by suction mode pump. This is because, in case of confined/pressurized aquifer (which is the case in this region), when the pumping is started, the cone of depression becomes sharp (very high) and the dynamic water level within the well becomes 3-5 $\mathrm{m}$ higher compared to the static water level $[32,33]$. At Adamdighi Upazila, the WT depths are declining within the limit from 6.06 to $11.02 \mathrm{~m}$ in all observation wells, and the decreasing rate for wells GT10006001, GT10006002, and GT10006003 are 0.084, 0.053, and $0.07 \mathrm{~m}$ /year, respectively (Figure 8). At Bogra Sadar Upazila, the hydrograph shows a decreasing trend, and varies within 5.59 to $9.10 \mathrm{~m}$ in three wells, while the decreasing rates are 0.02, 0.09, and $0.04 \mathrm{~m}$ /year for locations GT1020005, GT1020006, and GT1020007, respectively. In contrast, well GT1020004 shows an increasing trend, with a value of $0.02 \mathrm{~m} /$ year. At Dhunot, Gabtali, and Sonatola all wells run in and remain within the suction limit (from 3.27 to $7.99 \mathrm{~m})$. At Sariakandi, Nandigram, and Shibganj, nearly all of the wells fluctuate within the suction limit $(8 \mathrm{~m})$. This might be due to the flowing of the Jamuna River through Sariakandi Upazila, as well as conjunctive use of surface and groundwater for irrigation. At Dupchanchia Upazila, the WT depth varied within the suction limit (8 m) during 1981-1990. A drastic decline from 1991 to 1992 occurred, which is due to the missing data from July to December 1991 and low amount of rainfall (1382 mm) in 1992. After that, the WT depth gradually declines up to $10 \mathrm{~m}$. At Kahalu Upazila, two observation wells (GT1054013 and GT1054014) show fluctuations above suction limit between the years 1981 and 1987, and then gradually decline to $10 \mathrm{~m}$. At Sherpur Upazila, all observation wells are declining within 4.88 to $13.32 \mathrm{~m}$, while well GT1088023 shows a significant trend of $0.2 \mathrm{~m}$ /year.

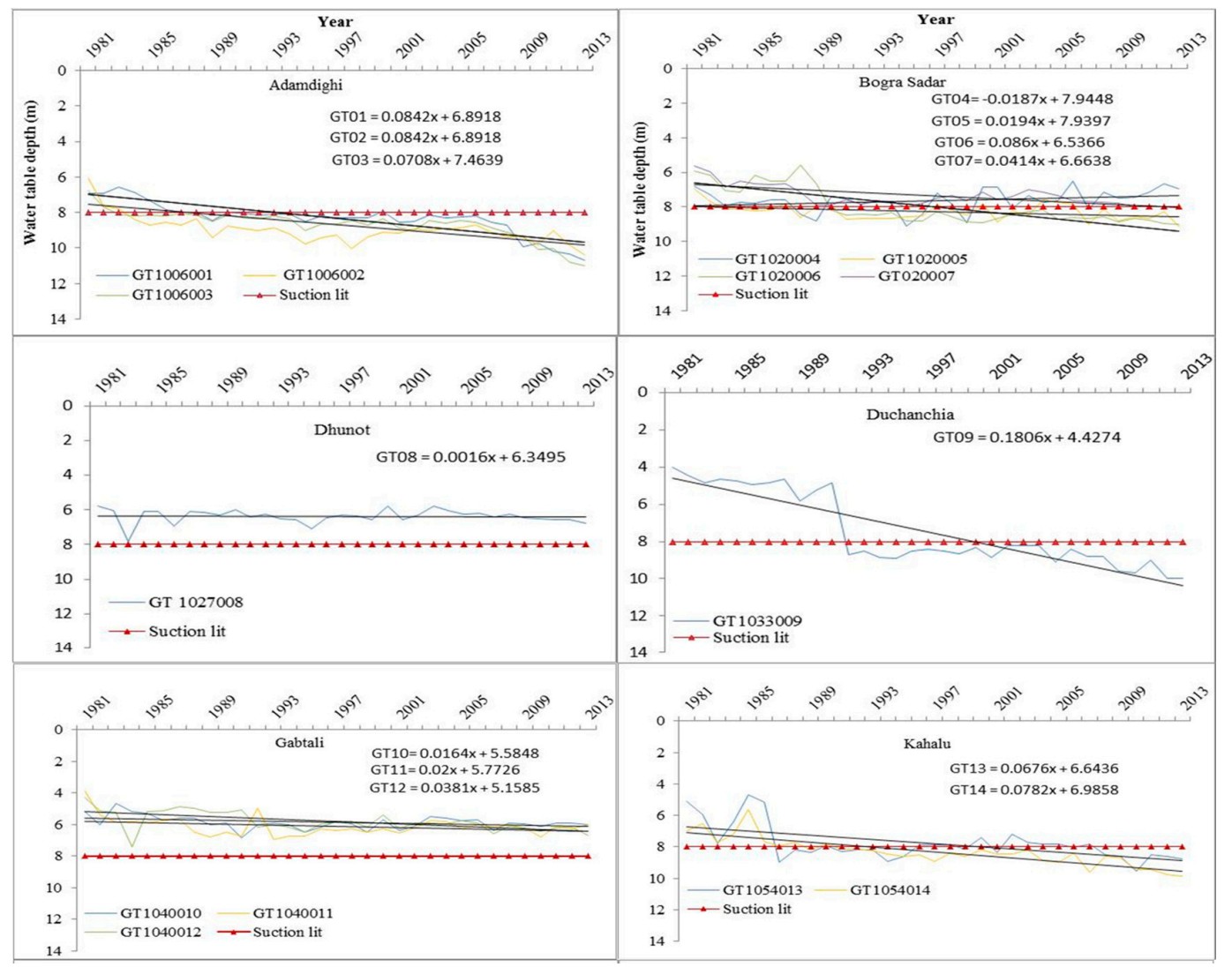

Figure 8. Cont. 


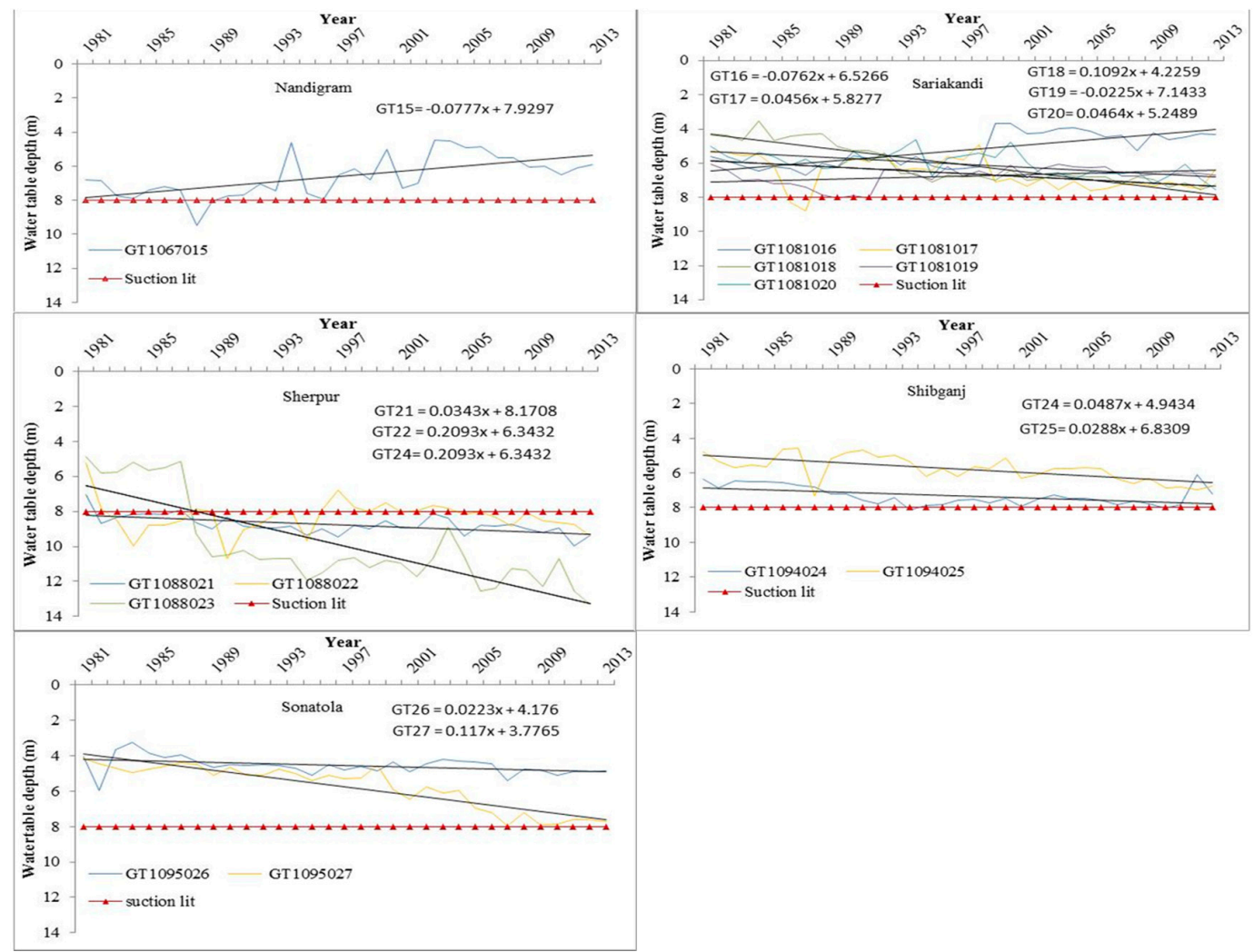

Figure 8. Long-term maximum WT depth fluctuation scenario for the study area.

Moreover, for the whole study area, result show reasonable spatio-temporal variation of maximum WT depth. For example, in 1981 and 2013, it varies from 3.86 to $7.07 \mathrm{~m}$ (mean: $5.55 \mathrm{~m}$ ) and 3.31 to $13.32 \mathrm{~m}$ (mean: $7.96 \mathrm{~m}$ ), respectively (Figure 9). During the observation period from 1981 to 2013 the average maximum WT depth fluctuation is $7.13 \mathrm{~m}$, thus indicating a long-term declining trend.

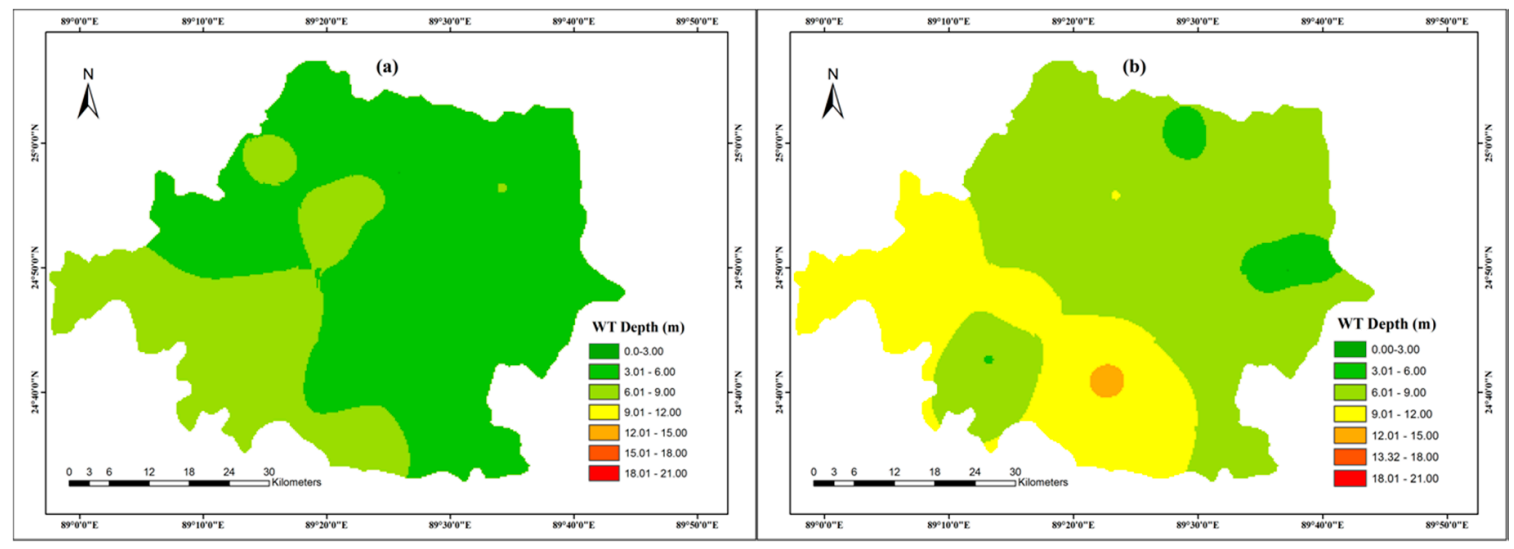

Figure 9. WT depth distribution (a) maximum in 1981 and (b) maximum in 2013 (using same legend).

\subsection{Future Projections}

The simulated WT depth fluctuation values from 1981 to 2013 are estimated using the MAKESENSE model. The distribution of simulated WT depth values for $95 \%$ and $99 \%$ confidence levels, along with the residual distributions, are shown in Figure 10. A negative tendency can be seen in the wells GT1020004, GT1067015, GT1081016, and GT1081019, which reveals more replenishment of the 
aquifer in this region than the other parts of the study area. The WT depth in other wells is anticipated to increase slowly, except for observation wells at Dupchanchia Upazila (GT1033009) and at Sherpur Upazila (GT1088023). Following the present trend of simulated values, using the same program, the projected values for the years 2020, 2040, and 2060 are also estimated. The spatial distributions of simulated maximum WT depth for the years 2020, 2040, and 2060 are shown in Figure 11. This shows if the present trend continues; the maximum WT depth in 2020, 2040, and 2060 will vary from 2.6 to $13.9 \mathrm{~m}$ (mean: $8.07 \mathrm{~m}$ ), 0.58 to $16.98 \mathrm{~m}$ (mean: $8.88 \mathrm{~m}$ ), and -1.44 to $20.07 \mathrm{~m}$ (mean: $9.69 \mathrm{~m}$ ), respectively. If the present trend continues, in many cases (e.g., three wells at Adamdighi, two wells at Bogra Sadar, two wells at Kahalu, three wells at Sherpur, two wells at Shibganj, and one well at Sonatola Upazila), the WT depth in the years 2020, 2040, and 2060 will go down below the suction limit.

Consequently, suction-mode pumps will not work and irrigation costs will be increased in such a situation. There are exceptions in some wells, such as well GT1027008 at Dhunot, and wells GT1040010, GT1040011 and GT1040012, at Gabtali. Using the same method, the predicted rainfall values are 1539, 1266, and $992 \mathrm{~mm}$ for the years 2020, 2040, and 2060, respectively. The predicted WT depth and rainfall values for 2020, 2040, and 2060 under different observation wells are given in Table 2.

Table 2. Position of WT depth and rainfall in the past, at present and in a simulated scenario for the future using MAKESENS software.

\begin{tabular}{|c|c|c|c|c|c|c|c|c|c|}
\hline \multirow{2}{*}{ Upazilla } & \multirow{2}{*}{ Well No. } & \multicolumn{2}{|c|}{ WT Depth $(\mathrm{m})$ in Year } & \multirow{2}{*}{ B } & \multirow{2}{*}{$\mathbf{Q}$} & \multicolumn{3}{|c|}{ Predicted WT Depth $(\mathrm{m})$ in Year } & \multirow{2}{*}{$\begin{array}{l}\text { Significance } \\
\text { Level of Trend }\end{array}$} \\
\hline & & 1981 & 2013 & & & 2020 & 2040 & 2060 & \\
\hline \multirow{2}{*}{ Adamdighi } & GT1006001 & 6.91 & 10.70 & 7.07 & 0.076 & 10.02 & 11.53 & 13.04 & $* * *$ \\
\hline & GT1006003 & 6.79 & 11.02 & 7.70 & 0.058 & 9.95 & 11.10 & 12.25 & $* * *$ \\
\hline \multirow{2}{*}{ Bogra Sadar } & GT1020004 & 6.79 & 6.97 & 7.88 & -0.019 & 7.13 & 6.75 & 6.37 & + \\
\hline & GT1020005 & 6.96 & 9.10 & 8.06 & 0.018 & 8.76 & 9.12 & 9.48 & + \\
\hline Dhunot & GT1027008 & 5.8 & 6.80 & 6.13 & 0.012 & 6.62 & 6.86 & 7.11 & + \\
\hline Dupchanchia & GT1033009 & 4.02 & 9.98 & 4.43 & 0.174 & 11.21 & 14.69 & 18.17 & $* * *$ \\
\hline \multirow{2}{*}{ Gabtali } & GT1040010 & 5.16 & 6.02 & 5.54 & 0.015 & 6.13 & 6.43 & 6.73 & + \\
\hline & GT1040011 & 3.86 & 6.01 & 6.04 & 0.007 & 6.32 & 6.46 & 6.60 & \\
\hline \multirow{5}{*}{ Sariakandi } & GT1081016 & 5.62 & 3.31 & 6.55 & -0.101 & 2.60 & 0.58 & -1.44 & $* * *$ \\
\hline & GT1081017 & 5.34 & 6.35 & 5.64 & 0.060 & 7.98 & 9.18 & 10.38 & $* * *$ \\
\hline & GT1081018 & 4.25 & 7.27 & 4.35 & 0.102 & 8.34 & 10.39 & 12.44 & $* * *$ \\
\hline & GT1081019 & 6.05 & 6.70 & 7.03 & -0.016 & 6.42 & 6.11 & 5.79 & + \\
\hline & GT1081020 & 5.16 & 7.55 & 5.40 & 0.046 & 7.21 & 8.14 & 9.07 & $* * *$ \\
\hline \multirow{3}{*}{ Sherpur } & GT1088021 & 7.07 & 9.35 & 8.31 & 0.030 & 9.48 & 10.08 & 10.68 & $* *$ \\
\hline & GT1088022 & 5.25 & 9.42 & 8.02 & 0.006 & 8.25 & 8.36 & 8.48 & \\
\hline & GT1088023 & 4.88 & 13.32 & 7.86 & 0.155 & 13.89 & 16.98 & 20.07 & $* * *$ \\
\hline \multirow{2}{*}{ Shibganj } & GT1094024 & 6.34 & 7.20 & 6.74 & 0.037 & 8.19 & 8.93 & 9.67 & ** \\
\hline & GT1094025 & 4.78 & 6.78 & 4.78 & 0.054 & 6.90 & 7.99 & 9.08 & $* * *$ \\
\hline
\end{tabular}

Notes: $\mathrm{B}=$ Intercept of linear regression equation; $\mathrm{Q}=$ Slope of linear regression equation; ${ }^{* * *}$ trend is significant at $\alpha=0.001 ;{ }^{* *}$ trend is significant at $\alpha=0.01 ;{ }^{*}$ trend is significant at $\alpha=0.05 ;+$ trend is significant at $\alpha=0.1$, rainfall unit in $\mathrm{mm}$. 


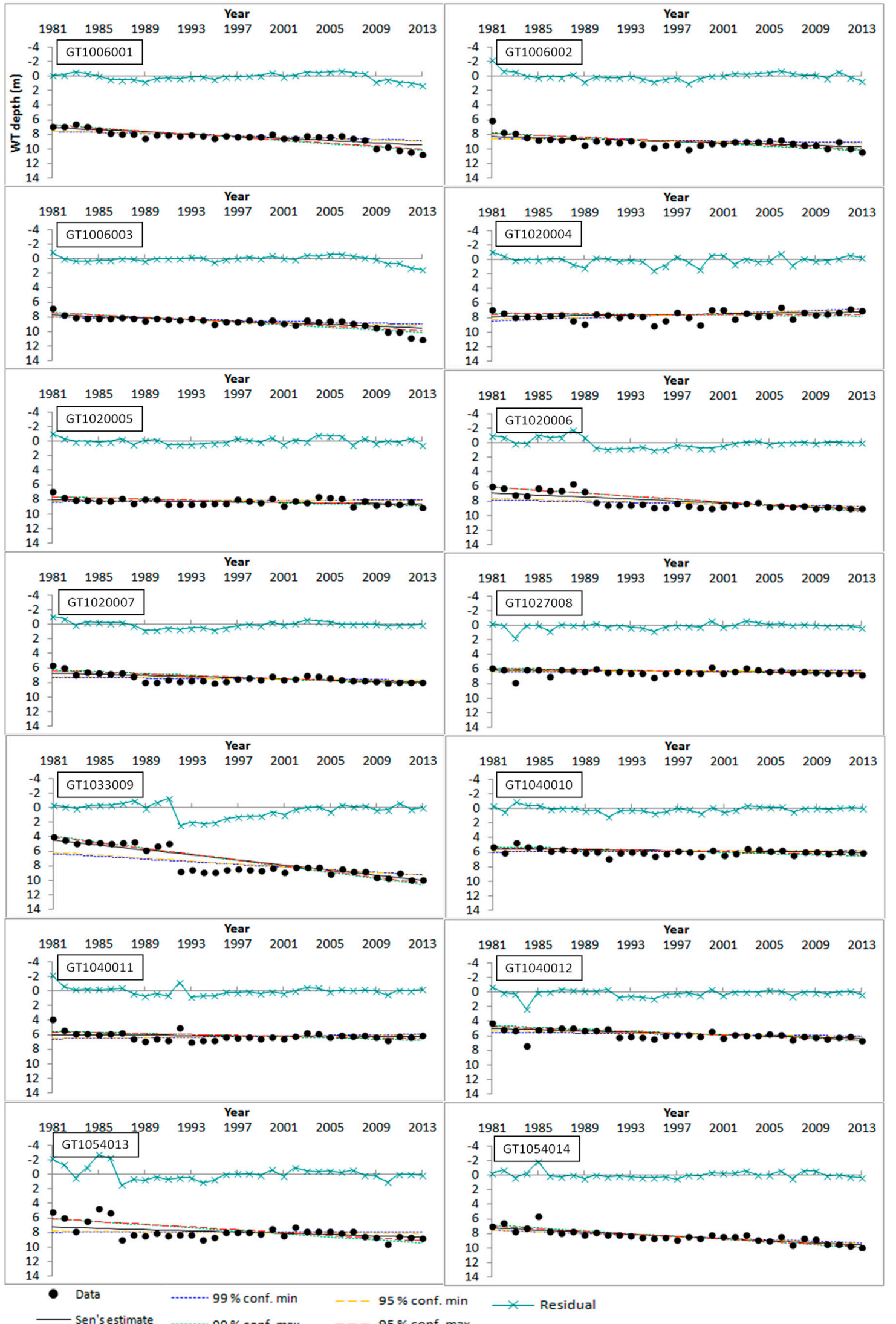

Figure 10. Cont. 


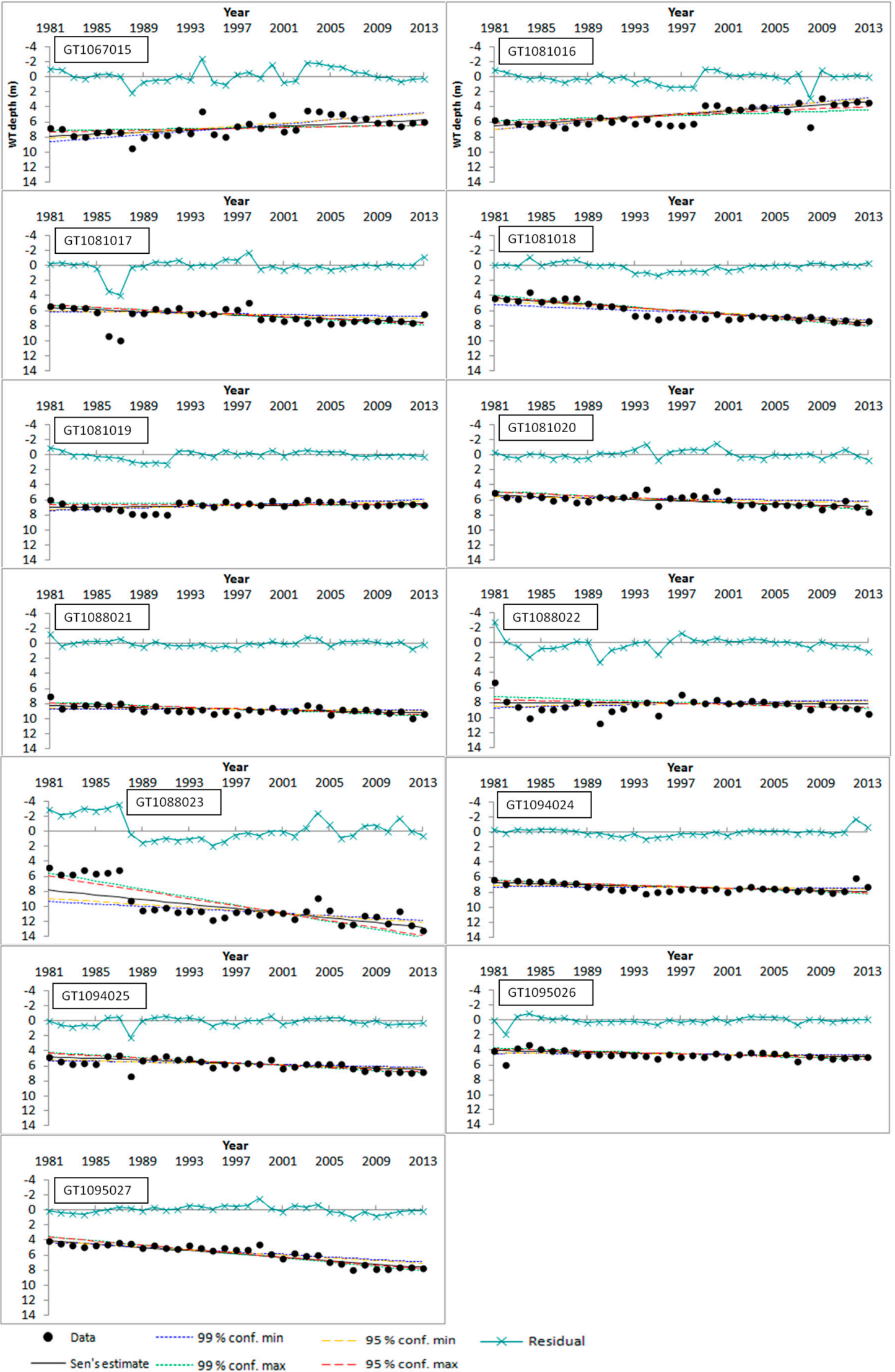

Figure 10. Trend of maximum fluctuation of WT depth for all of the observation wells. 


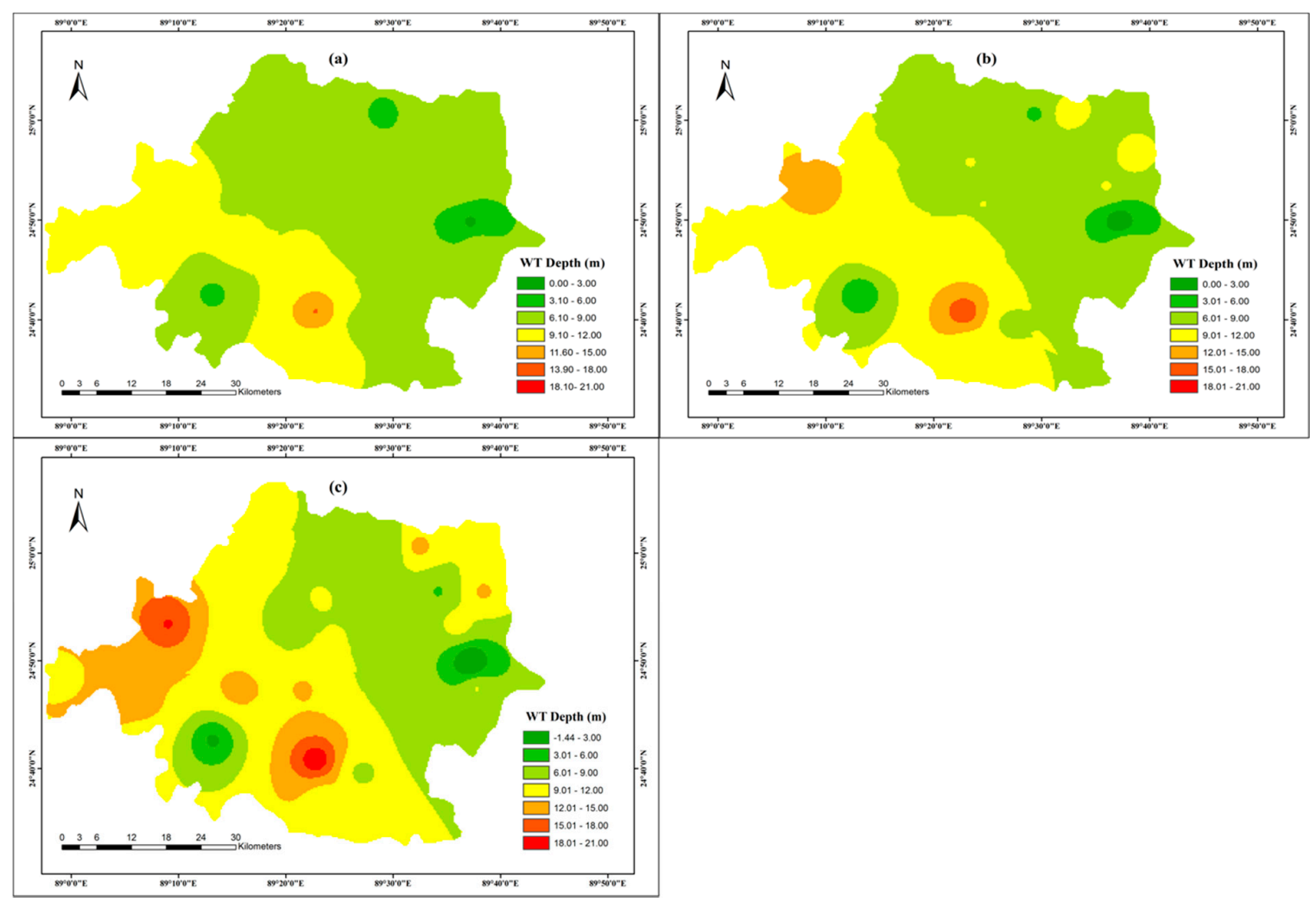

Figure 11. Simulated scenario of WT depth for (a) 2020; (b) 2040; (c) 2060.

\section{Discussion}

The stresses on groundwater for irrigation in Bangladesh have increased drastically over the last three decades and its contribution on irrigation increased from $41 \%$ in $1982-1983$ to $75 \%$ in 2001-2002 [34]. Moreover, the ratio of groundwater to surface water use is much higher in the Barind region compared to other parts of the country [19]. The long-term declining trend of WT depth in this study shows agreement with the Bangladesh Agricultural Development Corporation (BADC) report. However, the long-term WT depth fluctuation is a function of multifold variables (e.g., annual rainfall, annual groundwater withdrawal, and local subsurface conditions). In this analysis, most emphasis is given to the relation between long-term WT depth and annual rainfall because the pumping data is unavailable. On the basis of a sampling duration (1981-2013), the long-term average maximum WT depth is $7.13 \mathrm{~m}$. From a long-term future projection perspective, the predicted values for the years 2020, 2040, and 2060 are 1.13, 1.24, and 1.36 times higher than that of present trends. However, the WT depth present trend value and projected values for 2020 and 2040 are also dissimilar with that of values estimated by [19]. The yearly variation pattern of the WT depth reflects a greater depth during October-April and from May-September (rainy season) WT depth remains above the suction limit $(8 \mathrm{~m})$. Thus, during the dry season (e.g., October-April), WT depth goes beyond the suction limit as irrigation is given in this period, and this situation consequently limits the groundwater-fed irrigation. This variation is in agreement with the yearly rainfall variation pattern. In this analysis, it is found that maximum rainfall happens during May-September and the least amount in February-April. The correlation value (0.58) between long-term WT depth and rainfall shows a good dependency of groundwater on rainfall for replenishment. However, WT depth above suction limit is considered for groundwater based irrigation because in NW Bangladesh about 78\% irrigated land is covered by groundwater and approximately $80 \%$ groundwater is lifted by STW using the centrifugal pump, which has a suction limit of $8 \mathrm{~m}$ [35]. Although there are some exceptions, the WT depth continued to decline with a slight response to excess rainfall in monsoon or dry season months. This might be the cause 
of over-extraction of groundwater for irrigation and the slow rate of infiltration through the upper clay to silty clay layer. Sustainable management of groundwater requires that the extraction from a groundwater reservoir should be in equilibrium with the average recharge in the long-term, and the lowered groundwater levels be environmentally, economically, and socially acceptable. Gradually declining groundwater depths of the study area are an indicator of unsustainable extraction. In some cases, the depth will be approximately double the present value by the year 2060, if the present trend of withdrawal is continued. Consequently, it will increase the irrigation cost and, thus, impact crop production. In addition, a series of ecological and environmental issues (e.g., land subsidence and deterioration of water quality) may develop and become the key factors constraining socioeconomically sustainable development.

\section{Conclusions}

The WT depth of 27 observation wells from 11 Upazilas of the Bogra district for the period of 1981-2013 were analyzed to determine the trends and observe the WT dynamics. The hydrographs exhibit that the WT depth at the beginning and end of the study period vary spatially. However, except for a few cases, the WT depth showed a declining trend, and in many places, the WT depth falls below the lifting capacity (up to $8 \mathrm{~m}$ ) of suction-mode pumps.

Using the MAKESENS software, long-term predictions were projected considering the current rate of the WT depth trend. If the present trend in the dry season is continued, suction-mode pumps may not operate at all due to the exceeding the suction limit. The continuous dropping of the WT is the major principal reason of groundwater level instability. If this instability once appears, it will promote the appearance of many environmental calamities. Moreover, the sustainability of groundwater in Northwest Bangladesh has long been identified as a matter of concern. Therefore, an urgent measure should be adopted to avoid groundwater over-mining. Minor irrigated crops could be adopted instead of the monopoly of the rice cropping pattern. On-farm management of water, such as growing short-duration drought-tolerant or low water demand crops, applying water saving techniques (such as alternate wetting and drying), soil-water conservation through mulching, rainwater harvesting in farm ponds or surface water bodies, etc., should be adopted to avoid groundwater mining and to promote the sustainable use of groundwater resources. These strategies are expected to lead to the sustainable use of groundwater resources in the area.

Acknowledgments: This work was financially supported by Key Research Program of the Chinese Academy of Sciences (Grant No. KJZD-EW-TZ-G10) and by a fellowship from China Scholarship Council (Grant No. 2014GXYB21) at the Institute of Geographic Sciences and Natural Resources Research, University of Chinese Academy of Sciences. The authors thank the editor and anonymous reviewers for their helpful and constructive comments that greatly contributed to improve the quality of our paper.

Author Contributions: Mohammad Hasanuzzaman conceived and designed the study and contributed to the writing of the paper; Yinghua Zhang and Shakir Hussain participated in data processing; Xianfang Song and Dongmei Han reviewed the manuscript.

Conflicts of Interest: The authors declare no conflict of interest.

\section{References}

1. The future we want. In Proceedings of the United Nations Conference on Sustainable Development (UNCSD), RIO + 20, Rio de Janerio, Brazil, 20-22 June 2012.

2. Siebert, S.; Burke, J.; Faures, J.M.; Frenken, K.; Hoogeven, J.; Doll, P.; Portmann, F.T. Groundwater use for irrigation-A global inventory. Hydrol. Earth Syst. Sci. 2010, 14, 1863-1880. [CrossRef]

3. Huang, F.; Wang, G.H.; Yang, Y.Y.; Wang, C.B. Overexploitation status of groundwater and induced geological hazards in China. Nat. Hazards 2014, 73, 727-741. [CrossRef]

4. Harvey, C.F.; Ashfaque, K.N.; Yu, W.; Badruzzaman, A.B.M.; Ali, M.A.; Oates, P.M.; Michael, H.A.; Neumann, R.B.; Beckie, R.; Islam, S.; et al. Groundwater dynamics and arsenic contamination in Bangladesh. Chem. Geol. 2006, 228, 112-136. [CrossRef] 
5. Shahid, S. Spatial and temporal characteristics of droughts in the western part of Bangladesh. Hydrol. Process. 2008, 22, 2235-2247. [CrossRef]

6. Shahid, S.; Behrawan, H. Drought risk assessment in the western part of Bangladesh. J. Nat. Dis. 2008, 46, 391-413. [CrossRef]

7. Qureshi, A.S.; Ahmed, Z.; Krupnik, T.J. Groundwater Management in Bangladesh: An Analysis of Problems and Opportunities; Cereal Systems Initiative for South Asia mechanization and Irrigation (CSISA-MI) Project, Research Report No. 2; International Maize and Wheat Improvement Center (CIMMYT): Dhaka, Bangladesh, 2014.

8. Brammer, H. Agricultural Development Possibilities in Bangladesh; University Press Limited: Dhaka, Bangladesh, 1997.

9. Ali, M.H.; Abustan, I.; Rahman, M.A.; Haque, A.A.M. Sustainability of groundwater resources in the northeastern region of Bangladesh. Water Resour. Manag. 2011, 26, 623-641. [CrossRef]

10. Kirby, J.M.; Ahmad, M.D.; Mainuddin, M.; Palash, W.; Quadir, M.E.; Shah-Newaz, S.M.; Hossain, M.M. The impact of irrigation development on regional groundwater resources in Bangladesh. Agric. Water Manag. 2015, 159, 264-276. [CrossRef]

11. Asraf, T.; Ali, M.H. Water table dynamics and trend in three Upazilas of Rajshahi district (Barind area), Bangladesh. Asian Acad. Res. J. Multidiscip. 2015, 2, 286-310.

12. Qureshi, A.S.; McCornick, P.G.; Sarwar, A.; Sharma, B.R. Challenges and prospects of sustainable groundwater management in the Indus Basin, Pakistan. Water Resour. Manag. 2010, 24, 1551-1569. [CrossRef]

13. Anantha, K.H. Economic implications of groundwater exploitation in hard rock areas of southern peninsular India. Environ. Dev. Sustain. 2013, 15, 587-606. [CrossRef]

14. Gunaalan, K.; Asanthi, H.B.; Gamage, T.P.D.; Thushyanthy, M.; Saravanan, S. Geochemical variations of groundwater quality in coastal and karstic aquifers in Jaffna Peninsula, SriLanka. In Management of Water, Energy and Bio-Resources in the Era of Climate Change: Emerging Issues and Challenges; Capital Publishing Company: New Delhi, India, 2014; pp. 51-61.

15. Ali, M.H.; Islam, A.K.M.R.; Amin, M.G.M. Trend of temperature and rainfall over Bangladesh during the last five decades. J. Agrometeorol. 2007, 9, 26-33.

16. Devlin, J.F.; Sophocleous, M. The persistence of the water budget myth and its relationship to sustainability. Hydrogeol. J. 2005, 13, 549-554. [CrossRef]

17. Maheshwari, B.; Varua, M.; Ward, J.; Packham, R.; Chinnasamy, P.; Dashora, Y.; Dave, S.; Soni, P.; Dillon, P.; Purohit, R.; et al. The role of transdisciplinary approach and community participation in village scale groundwater management: Insights from Gujarat and Rajasthan, India. Water 2014, 6, 3386-3408. [CrossRef]

18. Alley, W.M.; Leake, S.A. The journey from safe yield to sustainability. Ground Water 2004, 42, 2-16. [CrossRef]

19. Rahman, A.T.M.S.; Kamruzzaman, M.; Jahan, C.S.; Mazumder, Q.H. Long-term trend analysis of water table using 'MAKESENS' model and sustainability of groundwater resources in drought prone Barind area, NW Bangladesh. J. Geol. Soc. India 2016, 87, 179-193. [CrossRef]

20. Morgan, J.P.; McIntire, W.G. Quaternary geology of Bengal Basin, East Pakistan and India. Geol. Soc. Am. Bull. 1959, 70, 319-342. [CrossRef]

21. Salmi, T.; Maatta, A.; Anttila, P.; Airola, T.R.; Amnell, T. Detecting Trends of Annual Values of Atmospheric Pollutants by the Mann-Kendal Test and Sen's Slope Estimates-The Excel Template Application MAKESENS; User Manual; Air Quality, Finish Meteorological Institute: Helsinki, Finland, 2002; p. 35.

22. Jahan, C.S.; Islam, M.A.; Mazumder, Q.H.; Asaduzzaman, M.; Islam, M.M.; Islam, M.O.; Sultana, A. Evaluation of depositional environment and aquifer condition in the Barind area, Bangladesh, using gamma ray well log data. J. Geol. Soc. India 2005, 70, 1070-1076.

23. Rashid, B.; Islam, S.U.; Islam, B. Sub-surface geology and evolution of the Barind Tract, Bangladesh. Am. J. Earth Sci. 2015, 2, 22-38.

24. Hirsch, R.M.; Slack, J.R.; Smithra, R.A. Techniques of trend analysis for monthly water quality data. Water Resour. Res. 1982, 18, 107-121. [CrossRef]

25. Thas, O.; Van Vooren, L.; Ottoy, J.P. Selection of nonparametric methods for monotonic trend detection in water quality. J. Am. Water Res. Assoc. 2007, 34, 347-357. [CrossRef]

26. Park, Y.C.; Jo, Y.J.; Lee, J.Y. Trends of groundwater data from the Korean national groundwater monitoring stations: Indication of any change? Geosci. J. 2011, 5, 105-114. [CrossRef] 
27. Gilbert, R.O. Statistical Methods for Environmental Pollution Monitoring; Van Nostrand Reinhold: New York, NY, USA, 1987.

28. Hossain, M. The Impact of Shallow Tube-Wells and Boro Rice on Food Security in Bangladesh; IFPRI Discussion Paper 00917-2020 Vision Initiative; International Food Policy Research Institute: Washington, DC, USA, 2009.

29. Ravenscroft, P.; Brammer, H.; Richards, K.S. Arsenic Pollution: A Global Synthesis; Wiley-Blackwell: Chichester, UK, 2009.

30. Bangladesh Agricultural Development Corporation (BADC). Minor Irrigation Survey Report 2012-2013; Bangladesh Agricultural Development Corporation, Ministry of Agriculture, Government of Bangladesh: Dhaka, Bangladesh, 2013.

31. Alam, M.S.; Islam, M.A. Long-term assessment of rice production scenario in Bangladesh: A macro dynamics. Bangladesh J. Agric. Res. 2013, 38, 257-269. [CrossRef]

32. Ali, M.H.; Abustan, I. Methods and approaches of groundwater investigation, development, and management. In Water Engineering; Dominic, P.T., Ed.; Nova Science Publishers, Inc.: New York, NY, USA, 2011; pp. 1-122.

33. Ali, M.H. Principles and Practices of Water Resources Development and Management; Nova Science Publishers, Inc.: New York, NY, USA, 2016.

34. Bangladesh Agricultural Development Corporation (BADC). Survey Report on Irrigation Equipment and Irrigated Area in Boro/2001 Season; BADC: Dhaka, Bangladesh, 2002.

35. Bangladesh Bureau of Statistics (BBS). Annual Agricultural Statistics 2008; Agricultural Wing, Bangladesh Bureau of Statistics: Dhaka, Bangladesh, 2009.

(C) 2017 by the authors. Licensee MDPI, Basel, Switzerland. This article is an open access article distributed under the terms and conditions of the Creative Commons Attribution (CC BY) license (http:/ / creativecommons.org/licenses/by/4.0/). 